\title{
The Once and Future Tragedy of the Cultural Revolution
}

\author{
Roderick MacFarquhar ${ }^{*}$
}

Let me start with a personal experience. Over many years at Harvard, I taught a course in the core programme on the Cultural Revolution. During the 1980s and 1990s, the students were mainly Americans, but in the new millennium, Harvard, like other US schools, began to admit undergraduates from China. Although some of them avoided my course because they reportedly feared I might insult Mao Zedong 毛泽东, quite a few risked this possibility. Many of those Chinese students came up to me at the end of the course to thank me for opening their eyes to the events of 1966-1976; mum and dad/grandma and grandpa had told them nothing about the Cultural Revolution.

My reaction to these revelations was that their ignorance must in part be owing to the vigorous attempt by the regime to consign the Cultural Revolution to the dustbin of history by discouraging research and teaching on the subject. Under those circumstances, parents and grandparents could be forgiven for not igniting their children's curiosity and perhaps exposing them to sanctions. But, other possibilities also occurred to me. Since most of the Harvard cohort of Chinese undergraduates are from bourgeois families, their relatives are unlikely to have escaped involvement in the Cultural Revolution: either they were beaten up, had their houses trashed, their books burned, their valuables confiscated, or they were among the beaters and looters. Either way, these would be deeply shaming experiences: would one really want to dwell on them with one's children? Louisa Lim entitled her book about Tiananmen The People's Republic of Amnesia. ${ }^{1}$ The title could be equally well applied to the Cultural Revolution.

The dangers of inducing national amnesia is encapsulated in George Santayana's famous dictum: "Those who cannot remember the past are condemned to repeat it." Or, as the Nobel Prize-winning author Gao Xingjian 高行健 put it when discussing the Cultural Revolution:

Furthermore, it is very likely that when people have forgotten about it, it will make a comeback, and people who have never gone crazy will go crazy, and people who have never been oppressed will oppress or be oppressed. This is because madness has existed since the birth of humanity, and it is simply a question of when it will flare up again. ${ }^{2}$

That is why the enterprise enshrined in this volume on the Cultural Revolution is well judged. There are still so many important questions, events and subjects that

* Harvard University. Email: macfarq@fas.harvard.edu.

1 Lim 2014.

2 Gao 2002, 195, quoted in MacFarquhar and Schoenhals 2006, 450. 
need to be explored further, and Fudan and The China Quarterly are to be congratulated on recruiting Chinese and Western scholars to tackle them together.

For most observers of contemporary China, the very obvious legacy of the Cultural Revolution is Deng Xiaoping's 邓小平 reform and opening up. As Chairman Mao was wont to say, although he would have refrained on this topic, "out of bad things come good things." The desperate plight of China in 1976, left far behind in the race for development by other peoples in the old Chinese cultural area, woke up the survivors of Mao's last folly to the need for new ideas and new directions. Fortunately, Deng Xiaoping had the courage and the clout to start crossing the river by feeling for the stones, to embrace any method which contributed to economic progress by calling it "socialism with Chinese characteristics," to proclaim that "practice is the sole criterion of truth" and not ideology, and to permit the widespread use of a slogan that was the very antithesis of the Cultural Revolution: "To get rich is glorious." As a result, over the past 35 years, the Chinese people have transformed their nation into the workshop of the world, and hundreds of millions of them have become prosperous to an extent undreamt of in the Maoist era. So, how likely is it that amnesia about the Cultural Revolution could bring about a repeat as Santayana and Gao would predict? What were the basic ingredients of the Cultural Revolution that might be replicable?

First, no Mao, no Cultural Revolution. One needs a supreme leader with a cult so pervasive that he can act with little danger of being questioned. Second, the supreme leader must sense danger so great - either to the system or to himself or to both - that he must take extraordinary measures to ward it off. Mao did not launch a cultural revolution in the 1950s, because he was only beginning to develop his obsession with the concept of revisionism, i.e. Soviet "abandonment" of Leninist doctrine. And, while Khrushchev's denunciation of Stalin in 1956 may have caused Mao to fear that his own doctrines might be abandoned after his death, it was only when Khrushchev was dismissed in 1964 that he may have begun to fear that his colleagues might unseat him even before his death.

Third, the leader must have a bulwark of support for any drastic measures like a cultural revolution. In Mao's case it was the PLA. Fourth, the leader must also have a gang of "trusties" who can be counted on to do his bidding, even in the face of a hostile party and society. Could those elements be reproduced today?

First, no Chinese leader can be Mao, revolutionary victor and founder of the People's Republic, and its leader for 27 years. But, Josif Dzhugashvili did not have to be Lenin in order to be Stalin. Within a leader-friendly system like Leninism, new supreme leaders can arise. Already, it is widely recognized that in a brief three and a half years, Xi Jinping 习近平 has become more powerful than his two predecessors. A healthy cult of Xi dada 习大大 is being developed. Seven major books with his writings and anecdotes, etc. have been published. There is a compendium entitled Approachable: The Charm of Xi Jinping's Words which, though large and yellow, apparently conjures up memories of Mao's "little red book." There is a song entitled "Xi Dada loves Mama Peng," 
and perhaps most significantly, an amulet which has Mao on one side and $\mathrm{Xi}$ on the other. ${ }^{3}$

Second, are there system-threatening dangers in China? The Party and state have been described by Jiang Zemin 江泽民, Hu Jintao 胡锦涛 and Xi Jinping as in danger of collapse because of corruption. This is what has aroused Xi Jinping to launch his hard-driving anti-corruption campaign. The campaign is to target Party officials, high and low, "tigers" and "flies." Unlike Mao's Cultural Revolution, in which the violence was often random and gratuitous, this campaign will zero in on known corrupt officials.

Third, Xi has also emulated Mao in indicating that the PLA is his bulwark by getting 18 senior generals to pledge their allegiance. Finally, Xi Jinping has no "gang of four," but he has far more powerful weapons: the Party secretariat and the Central Discipline Inspection Commission (CDIC), led by his old friend and colleague, Wang Qishan 王岐山.

And yet, surely there is no possibility of a repeat of the Cultural Revolution. What leader with any knowledge of the killing and chaos of that period would want to repeat it? What leader would be so confident as to feel his leadership would not be challenged if he tried to? Xi Jinping is, above all, the trumpeter of the "Chinese dream," the rejuvenation of the Chinese nation. He has no interest in throwing the country into confusion, as Mao did. His obsession is how to avoid what happened to the Soviet Union and the Soviet Communist Party. He seeks to do that by ridding the Chinese Communist Party (CCP) of corruption.

But, there's the rub. Mao wanted to make China's leaders revolutionary, whereas Xi seeks to make them pure. The aims may be different, but in a very real sense what $\mathrm{Xi}$ is attempting is also a cultural revolution. It may not be a "great revolution that touches people to their very souls," 4 but the anti-corruption campaign touches their families, their wealth and their positions. Everything that Party members have worked for or schemed for over the past 35 years is at risk. As in Mao's Cultural Revolution, the highest in the land are not to be spared. Zhou Yongkang 周永康, a member of the ruling Politburo Standing Committee (PSC) and the boss of the security apparatus and law enforcement until he retired at the last Party congress, is the biggest tiger to have been brought down so far. The rumoured convention that PSC members are sacrosanct even in retirement has been breached. Zhou is not a Liu Shaoqi 刘少奇, but he was a formidable figure, even after leaving office. General Xu Caihou 徐才厚, a former Politburo member and vice-chairman of the Party's Military Affairs Commission, was not spared from indictment even though he was dying of cancer. Again, $\mathrm{Xu}$ was no Lin Biao 林彪 but he was as senior a military officer as one can find these days.

3 See Phillips, Tom. 2014. "Xi Jinping: the growing cult of 'Big Daddy Xi'," The Telegraph, 8 December, http://www.telegraph.co.uk/news/worldnews/asia/china/11279204/Xi-Jinping-the-growing-cult-of-ChinasBig-Daddy-Xi.html. Accessed 28 April 2016.

4 The quote is from the 16-point decision on the Cultural Revolution passed at the Central Committee's 11th Plenum in August 1966. 
The CDIC strategy used against tigers is designed to cut away all defences before striking, like cutting down small trees and clearing undergrowth before felling a giant sequoia or a Douglas fir. Zhou's associates from the various places where he had worked and developed loyalty to himself were arrested first. Doubtless, officials under pressure will reveal all about the corruption of their bosses, friends or colleagues if it means a lighter punishment for themselves.

But, how long can this process continue? In Mao's Cultural Revolution, nobody dared even to try to rein in the chairman. Xi has not reached that eminence yet, and there must be some current colleagues or retired grandees like Jiang Zemin who feel the campaign is getting out of hand, or more basically, that they may be the next tiger for indictment. Will they really sit quietly and do nothing to stop $\mathrm{Xi}$ and Wang before it is too late?

And what about the flies? During the Cultural Revolution, the Party machine was trashed and, if they were lucky, lower officials only lost their jobs, but many were publicly denounced, beaten, maimed or even killed. There is no solid evidence as to whether torture is being used in the anti-corruption campaign, and certainly there is no repetition of the Red Guard rampages. But already thousands of officials have been brought to book and the whole campaign cannot but be demoralizing for those who fear they may be next. And, if corruption is as pervasive as CCP leaders claim, then they probably will be next!

In Mao's Cultural Revolution, up to 1.5 million people may have been killed according to Andrew Walder's research, but 100 million people were affected according to post-Mao official accounts. Similarly, in Xi's cultural revolution, the collateral damage will be far greater than the number of officials indicted. As the revelations of the CDIC and the investigations of Bloomberg News and New York Times reporters have confirmed, for every cadre officially designated as corrupt, there is quite possibly also a spouse, a child, a sibling or an in-law deeply involved. So, the social devastation of Xi's campaign, if carried through firmly to the end as he has promised, would be massive, going far beyond whatever proportion of the CCP's 85 million members are corrupt.

Will the leaders and the led of the CCP put up with that prospect? That is the considerable risk that Xi Jinping is taking with his cultural revolution.

\section{Biographical note}

Roderick MacFarquhar is the Leroy B. Williams Research Professor of History and Political Science at Harvard University. His works on China include three volumes of The Origins of the Cultural Revolution, two volumes of the Cambridge History of China (edited with John K. Fairbank), and Mao's Last Revolution (co-authored with Michael Schoenhals). In previous personae, he was a journalist (print, radio and TV), founding editor of The China Quarterly, and an MP. 


\section{References}

Gao, Xinjian. 2002. One Man's Bible. New York: Harper Collins.

Lim, Louisa. 2014. The People's Republic of Amnesia: Tiananmen Revisited. New York: Oxford University Press.

MacFarquhar, Roderick, and Michael Schoenhals. 2006. Mao's Last Revolution. Harvard: Harvard University Press and Belknap Press. 